Logos Universality Mentality Education Novelty, Section: Social Sciences

ISSN: $2284-5747$ (print), ISSN: $2284-5747$ (electronic)

Covered in: CEEOL, Index Copernicus, Ideas RePEc, EconPapers, Socionet

\title{
PARENTAL WORK FROM A SOCIOLOGICAL PERSPECTIVE
}

\section{Gabriela BEREA}

Logos Universality Mentality Education Novelty, Section:

Social Sciences, IV (1), 183-193

The online version of this article can be found at:

http://lumenjournals.com/social-sciences/

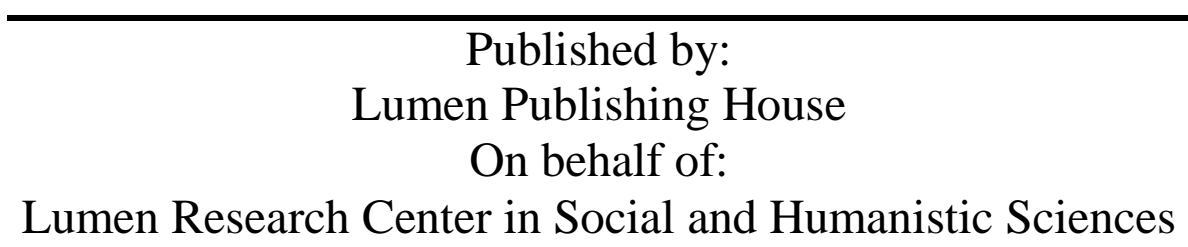




\title{
Parental Work from a Sociological Perspective
}

\section{Gabriela BEREA $^{1}$}

\begin{abstract}
Communication within the family is one of children's main educational experiences. The way in which parents communicate both among themselves and with the children determines education and some of its specific characteristics that unfold as communication style and also education style. The development of children's personalities due to parental influences is recognized and analysed in different theoretical researches and practical investigations. When talking about parental work, the focus is actually on their efforts with their own children. Looking at this in terms of practical duties (material occupation) and mental preoccupation (availability), the concept of parental work includes the definition of parent, father or mother, and its perpetuation - meaning its continuity in the child that is not exactly the same nor is it totally different. Also, the concept of "parental work" underlines decades of changes: it no longer is only about "doing" silently, but also about a work that can be quantified and that, in the meantime, has gone through a process of objectification and is now seen as work, as a job or a career - as a set of partly dissociated consequences of a naturalization between father and mother in an initial phase.
\end{abstract}

\section{Keywords}

parentality, parental work, competencies, education style.

1 Professor PhD, Liceul Teoretic "Vasile Alecsandri", Iaşi, România, gabiberea16@yahoo.com, 0741057579.

Berea, G. (2015). Parental Work from a Sociological Perspective. Logos Universality Mentality Education Novelty, Section: Social Sciences, IV (1), 183-193. 


\section{Familia şi educaţia copilului}

Comunicarea în familie reprezintă una din principalele experiențe educative ale copiilor. Modul în care părinții comunică între ei şi cu copiii, determină educația şi unele caracteristici specifice ale acesteia, care se conturează ca stil de comunicare, şi totodată ca stil educativ. Viața de familie în special, experiențele trăite din care se învaţă direct şi temeinic, comunicarea cotidiană mai ales cu părinții, determină formarea personalităţii şi a stilurilor specifice:

a) stilul cognitiv ca ,ansamblu de modalități particulare de dobândire, înmagazinare, transformare şi utilizare a informației" (Legenre, R., 1993, pag. 1194-1195) şi mai ales ca o manieră de a înțelege situațiile şi de a căuta soluții;

b) stilul afectiv ca un ,ansamblu de fațete ale personalității reliefate prin motivație, emoții, stimă de sine" (Legenre, R., 1993, pag. 1194).

Aceste stiluri reprezintă modalități de manifestare a personalităţii ce începe să se contureze din primii ani de viață.

Scopul propus în studiul de faţă este acela de a evidenția contribuția practicilor parentale în crearea unui spațiu necesar dezvoltării legăturii cu familia, mai exact conturarea unei idei despre locul şi statutul de părinte.

Obiective urmărite:

1)Definirea stilurilor parentale

2)Perspectiva sociologică a parentalității

3)Exercitarea autorității parentale

4)Practicile parentale versus constrângerile şcolare

Conceptul de personalitate, aşa cum l-a utilizat Allport, începând cu 1937, reprezintă modele relativ uniforme şi stabile de comportament pe care indivizii le manifestă şi le repetă în activitățile cotidiene (Legenre, R. 1993, pag. 1195). La preadolescență, personalitatea devine treptat conştientă de sine, îşi experimentează şi îşi pune în evidenţă stilurile.

Dezvoltarea personalității copiilor datorate influenței parentale este recunoscută şi abordată în diferite cercetări teoretice şi investigaţii concrete. Teoreticienii atașamentului consideră că un anumit patern al interacțiunii părinte-copil influențează dezvoltarea încrederii de sine, dezvoltarea unui sens autentic al sinelui, ce conduce spre independență şi spre autoevaluare pozitivă sau negativă (Strage, Amy A., 1998, pag. 74). La preadolescență nevoia de afecțiune și de ataşament parental nu scade 
chiar dacă începe să se manifeste tendinţa de depăşire a influenţelor mediului familial.

Noțiunea de "muncă" a intrat şi în vocabularul "educației domestice". Ea apare datorită curentului feminist materialist care, în anii 1970, şi-a propus să scoată economia familială din starea invizibilă în care se găsea în secolul al XIX-lea (Christine Delphy, 1998, pag.84). În acelaşi timp, nu poate fi disociată de un alt curent care, în 1930, a lansat o nouă direcție, în sensul unei "educări a părinților", a unei obiectivări a sarcinilor de lucru, a gesturilor şi a preocupărilor considerate până atunci o capacitate naturală a oricărui adult care are în îngrijire un copil. Din acel moment, noțiunea oscilează între recunoaşterea acestei "activităţi”" ca o "muncă în sine" şi tentaţia mereu prezentă de a transforma această “competență" într-o trambulină pentru responsabilizarea familiilor.

\section{Parentalitatea}

\section{II.1.Perspectivă sociologică- munca parentală}

Când se face referire la munca părinţilor se vorbeşte de fapt despre munca pe care aceştia o desfăşoară pentru proprii copii. Considerat în termeni de sarcini practice (ocupație materială) şi preocupare mentală (disponibilitate), conceptul de muncă parentală include definiţia părintelui în sine, tată sau mamă, şi perpetuarea sa adică prelungirea sa în persoana copilului care totuşi nu este la fel, dar nici total diferit. Totodată noțiunea de "muncă parentală" subliniază schimbările suferite în unul sau mai multe decenii: nu mai este vorba doar să "faci" în mod tacit, ci de o muncă care poate fi cuantificată şi care, în timp, a cunoscut un proces de obiectivare, fiind înțeleasă ca o muncă, un serviciu, o carieră, competențe disociate (în parte) a unei naturalizări între tată şi mamă în fază inițială.

Educația parentală a cunoscut de-a lungul vremii mai multe definiri, adaptate tipului de societate, de cultură şi bineînțeles modelului educaţional promovat la fiecare perioadă. Realizarea ei s-a bazat pe modelele tradiționale preluate şi transmise de la o generație la alta şi care au vizat practici parentale prin care îi învățau pe părinți să-şi exercite rolul de părinte în toată complexitatea lui. Aceste modele şi bune practici tradiționale nu mai corespund, în cea mai mare parte, cerințele generațiilor actuale, motiv pentru care s-au încercat şi alte mijloace de susţinere a familiei, prin diferite forme de intervenție educativă. 
Ca domeniu de cercetare, educația parentală este relativ recentă, fiind definită ca "o tentativă formală de creştere a conştiinţei parentale şi de utilizare a practicilor parentale" (Văşmaş, E., 2002, pag. 165) în vederea educației copiilor. Părinţii desfăşoară o activitate voluntară de învăţare, se formează şi se străduiesc să-şi modifice modul de interacțiune $\mathrm{cu}$ copiii lor, în favoarea educației copiilor, în scopul încurajării comportamentelor pozitive, a descurajarii celor negative şi a creşterii adaptabilității lor la realitatea existentă. (M. Ionescu, E. Negreanu, 2006, pag. 131).

Conţinutul muncii parentale pune accentul, în special, pe munca afectivă (cine acoperă diferitele investiții) şi cognitivă care o însoțeşte (ce trebuie făcut? cum? de cine?). Condiție implicită a reuşitei şcolare, sociale, dar mai ales "personale" a copiilor, munca parentală implică, pentru adulții care o prestează, o serie de compromisuri şi o ierarhie a priorităţilor revizuite permanent de-a lungul "carierei" parentale. Este vorba deci de o muncă care evoluează în timp şi spațiu în funcție de anumiți factori materiali (configurația familială, mediul social, organizarea pieței muncii, resursele oferite de contextual social) şi de investițiile şi înțelegerile realizate de principalii actori pentru ei înşişi şi în cadrul grupului conjugal/familial şi social. Astfel se creează un spațiu necesar dezvoltării legăturii cu familia, mai exact conturarea unei idei despre locul şi statutul de părinte.

Munca parentală este caracterizată în primul rând de dependența copiilor care necesită îngriijirea permanentă şi coabitarea, o miză importantă la nivelul formării identității. $\mathrm{O}$ altă caracteristică dominantă a muncii parentale este obligația privind rezultatele, concretizată în termeni de reuşită socială sau de satisfacere a criteriilor personale; aceasta dispare sau se transformă, atunci când munca din cadrul legăturii parentale este preluată de altă persoană decât părinții.

Privită din perspectiva obligațiilor sociale, şcoala ocupă fără îndoială un loc important în munca parentală, care este de altfel şi o muncă şcolară. Poate exista o diferență între logica privind socializarea în familie şi aşteptările şcolare şi educative de la şcoală. Dacă asistăm la un declin tot mai pronunţat al modelului familial tradițional, această discrepanţă este şi mai evidentă. În acest sens, împărţirea responsabilităților casnice între parteneri este susținută de politicile publice care, în mod hotărât, au plasat femeile pe un loc secundar pe piața muncii. Problema privind raportul muncă-familie o priveşte 
exclusiv pe mamă şi, în funcție de cultura profesională, ea poate fi gestionată cu mai mult sau mai puțin efort, dar şi delegată celuilalt părinte, în cazuri rare. În ultima vreme, putem spune că s-a schimbat viziunea generală asupra muncii parentale a taților, ceea ce conduce la concluzia că repartiția tradițională a rolului şi sarcinilor poate depăşi limitele cuplului clasic. În afară de asumarea normelor, munca parentală poate fi împărțită ținând cont de constrângerile economice ale clasei sociale, dar şi de fiecare dintre membrii cuplului. Problema educaţiei parentale sau a responsabilizării părinților poate fi mai bine înțeleasă, punându-se accentul pe condiţiile efective şi limitele autonomiei înțelegerilor dintre părinți. În prezent mediul social şi cultural în care se dezvoltă familia se regăseşte într-o dinamica continuă, fapt ce şi impune mereu o adaptabilitate a familiei. Copiii, părinții, comunitatea se influențează reciproc. Din această perspectivă "copilul este considerat în centrul unei rețele alcătuită din instituții şi persoane; numărul polilor, diversitatea lor, strategiile familiale cu privire la contactele exterioare ale copiilor, competențele atribuite fiecarui pol constituie indicatori ai experienței sale sociale. (...) Strategiile educative ale familiilor contemporane iau naştere la intersecția tuturor acestor poli, care funcţionează ca tot atâtea ansambluri de constrângeri externe, dar şi ca tot atâtea resurse” (Stănciulescu, E., 2002, pag. 24-25). Acest fapt generează şi tensiuni în exercitarea practicilor parentale atât în legătura directă cu logica şcolară, în materie de activităţi şcolare, cât şi în registrul domestic.

Există numeroase exemple de practici parentale puse în dificultate de constrângerile şcolare. Modalitățile de socializare ale familiilor sunt expuse în cadrul relației părinte-şcoală. Subordonate exigențelor şcolare, practicile acestor familii se confruntă cu normele educative impuse de şcoală şi de profesori şi deseori sunt supuse judecăţilor morale depreciative. Părerile în materie de educație nu sunt niciodată pur tehnice, dar implică mereu o conotație morală (Leger şi Tripier, 1986, pag. 85). Părinții sunt obligați să se situeze prin raportare la exigențele şi normele şcolare din domeniul educaţiei. Această constrângere atinge nivelul maxim când dificultățile de la şcoală duc la implicarea largă a psihologului, educatorului sau uneori a reprezentanților justiției, ca în cazul elevilor în abandon şcolar. Astfel, se conformează principiului ambivalenței făcându-i pe părinţi să oscileze între rezistență şi supunere faţă de normele şcolare privind socializarea. 
Pe de altă parte, practicile parentale exercitate în registrul domestic generează constrângeri de natură diversă. De exemplu în ceea ce priveşte sănătatea copiilor, şcoala promovează practici de prevenție şi acţiuni pentru a menține echilibrul fiziologic şi psihologic, sinonim cu sănătatea, conform concepției dominante despre aceasta din urmă. Ori în interiorul practicilor parentale din familiile obişnuite, mai ales în cele cu o situație materială precară, intervin şi alte sensuri. Boala este percepută mai degrabă ca o agresiune externă decât ca rezultatul unui dezechilibru fizic, prin raportare la percepția lumii văzută ca o amenințare. Practicile evidențiază rolul protecției copilului vizavi de posibilele agresiuni din partea mediului înconjurător şi nu puterea de anticipare cu scopul de a crea un mediu sănătos. Astfel, părinţii pot acționa impulsiv atunci când apar deja semne specifice ce indică o afecțiune a sănătăţii copilului. Practicile iau forma unei acțiuni imediate pentru a îndepărta pericolul: merg la medic atunci când copilul acuză durerea sau prezintă o stare febrilă. Sunt mai puține practici de prevenție. Ideea de a merge periodic la doctor pentru investigații când copiii sunt sănătoşi este ignorată de o mare parte a părinților care nu permit anticiparea şi punerea în practică a prevențiilor. Aici practicile parentale se intersectează cu logica şcolară şi sanitară şi sunt expuse criticii, din partea instituțiilor şcolare, sociale şi sanitare.

Analiza muncii parentale în cadrul claselor medii şi superioare evidențiază tensiunea pe care o suscită coexistența a două tipuri de obiective dificil de împăcat, pe de o parte, respectul faţă de autonomia copilului, părinții din aceste medii sociale declarându-se ataşați acestei categorii (Singly, 1998, pag. 165) şi, pe de altă parte, necesitatea de a limita practicile şi alegerile pe care ei le consideră cruciale pentru viitorul copiilor lor. Resursele economice, culturale şi sociale de care dispun aceste familii le permit, în numeroase cazuri, să modeleze opțiunile în mod discret şi continuu, fără să suscite reacții negative din partea copiilor. Această modelare ia forme diferite dacă este vorba despre părinți apropiați de polul managerilor sau de cel al intelectualilor şi în funcție de stilul familial existent, iar deschiderea către cunoaştere şi interesul pentru o dezvoltare personală conştientă este cu atât mai mare, cu cât este mai ridicat nivelul de instruire al părinților.

Funcțiile îndeplinite de familie contribuie la definirea unui stil educativ specific. Climatul familial pozitiv, protector şi stimulativ sau climatul negativ, distructiv şi inhibitor sunt determinate de maniera în 
care se realizează funcțiile interne şi externe ale familiei şi conduc la efecte educative, pozitive sau negative, asupra partenerilor şi a copiilor.

Activităţi desfăşurate în cadrul familial au scopul de a satisface nevoile specifice fiecărui membru şi familiei totodată:

-nevoile fiziologice: de hrană, igienă, sănătate;

-nevoi de siguranță: securitate, stabilitate, protecție (locuire, îmbrăcăminte);

-nevoi de actualizare de sine: împlinire personală, îmbogațirea propriului potențial;

- nevoi de dragoste şi apartenență: acceptare, dăruire şi primire a iubirii;

-nevoi de stimă: respect faţă de sine, respect faţă de alţii (Stănciulescu, E., 1997, pag. 134)

\section{II.2. Perspectivă juridică - autoritatea parentală}

Termenul de ,autoritate parentală” s-a folosit în România cu ocazia adoptării noului Cod civil, pornind de la exemplul codului civil francez. Noțiunea „autoritatea parentală” este relativ nouă şi în Franța; a fost introdusă în anul 1970, cu scopul de a înlocui noțiunea de „putere maritală"" (sau "autoritate paternă"), termen ce decurge din Codul civil Napoleonian. Introducerea autorităţii parentale în Franţa a constituit dovada egalizării îndatoririlor soțului şi soției: "cei doi soţi asigură impreună direcția morală și materială a familieì»: autoritatea parentală inlocuiesțte puterea paternă" (Codul Civil al României, pag.7). „Autoritatea părintească” sau „responsbilitatea părintească” reprezintă ansamblul de drepturi și îndatoriri având ca finalitate interesul copilului. Este exercitată de părinţi până la vârsta majoratului copilului pentru a-l proteja în ceea ce privesț siguranţa, sănătatea și moralitatea, pentru a-i asigura educația și dezvoltarea, in spiritului respectului față de propria persoană. Conform acestei obligații părinții trebuie să-l consulte pe copil în legătură cu deciziile care îl privesc, în funcție de vârstă și gradul de maturitate" (Codul Civil al României, Art.22. Alin.1).

Calitatea de părinte este stabilită prin filiație, iar autoritatea parentală este exercitată de ambii părinți, indiferent dacă sunt căsătoriți, uniți civil sau doar simpli concubini. Părinții au dreptul de a lua orice decizie necesară pentru binele copilului lor; pot hotărî unde anume va locui copilul, pot să permită sau să refuze îngriijirile de sănătate pentru el, 
ii pot transmite credințele lor religioase, pot decide alegerea şcolii, activitățile şi modul de petrecere a timpului liber.

Părinții pot delega autoritatea parentală, temporar, către o alta persoană, având posibilitatea de a limita drepturile si obligațiile acelei persoane. Este cazul copilului care merge într-o instituţie şcolară, autoritatea fiind delegată cadrului didactic. Aşadar autoritatea asupra copilului este împărțită între practicile curente de delegare a autorităţii (când copilul este lăsat în instituțiile şcolare, responsabilitatea revine cadrului didactic până în momentul în care iese din teritoriul şcolii; alte situații sunt cele uzuale între membrii, cunoştintele apropiate familiei, când pentru o perioadă foarte scurtă de timp aceştia, la rugămintea părinților, au grijă de copil) şi între măsurile juridice de delegare a autorității.

Autoritatea parentală ia sfârşit când copilul devine major ori atunci cand tribunalul decide asta, pe motiv că nu răspunde adecvat nevoilor materiale, afective şi intelectuale ale copilului sau când afectează negativ dezvoltarea acestuia. Astfel de situații sunt abandonul copilului, violenta, abuzul sexual.

Problematica ajutorului privind parentalitatea pare să constituie astăzi un element structurant în reflecțiile şi intervențiile organelor administrative care se ocupă de justiție, sănătate, de domeniul social sau familial. Părinții sunt cei care se află în mijlocul acestor dispozitive. De aceea trebuie să fie informați, responsabilizați dar totodată, susținuţi de structurile sociale sau educative din jur. Totuşi, acest tip de sprijin nu trimite la o referinţă cu o activitate stabilă şi bine definită. Pe de o parte constituie un instrument de control social iar pe de altă parte contribuie la transformarea intervenţiei sociale din respect pentru persoană şi idealul drepturilor omului.

Acțiunile destinate să susțină parentalitatea vizează astfel să instituie rolul diferiţilor membri ai familiei, oricare ar fi structura acesteia, şi să favorizeze dialogul şi schimburile între membrii unei familii, între familii, şi între familii şi profesionişti. Este vorba deci, în sens larg, de a integra în sânul acțiunii de prevenție toate mijloace de a-i ajuta pe părinți în meseria de părinte, într-o logică care îi respectă pe indivizi şi le valorizează competențele parentale. În principiu sunt vizaţi toți părinții, chiar dacă unii părinți par să aibă nevoie de mai mult ajutor.

Obiectivul acestor practici este acela de a garanta copilului o securitate materială şi afectivă independentă de aspirațiile individuale şi libertăţile de care fiecare părinte se poate prevala. Nevoia de siguranță 
pe care o are copilul se identifică cu nevoia de a fi crescut de proprii părinți.

Sprijinul pentru parentalitate se manifestă prin acțiuni vizând populația țintă: familiile monoparentale, cuplurile tinere slăbite de rupturile familiale, familiile afectate de degradarea stării profesionale. Reflecția pleacă de la principiul că ceea ce este dificil pentru toate familiile este şi mai dificil pentru cei expuşi riscurilor vieții, şi mai ales nesiguranței materiale. In cazurile cele mai grave de maltratare sau neglijență, obiectivul este de a apropia profesioniştii de familii şi, în pofida lucrurilor, de a-i ajuta să valorifice familia ca loc de competenţă.

\section{Influența constrângerilor educaţionale şi sociale în exercitarea parcticilor parentale}

În calitate de cercetător dar şi de cadru didactic, mi-am propus să incerc să conturez modul în care este percepută practica parentală din perspectiva colegilor mei, cadre didactice în Iaşi.

Scopul studiului a fost să fac cunoscută opinia cadrelor didactice referitoare la relaționarea părinte-profesor-elev şi la impactul acesteia asupra evoluției şcolare şi sociale a copiilor implicați.

Populația la care am făcut apel în acest studiu este formată din specialişti implicați în mod direct în actul educațional al elevilor, respectiv învăţățori, profesori, institutori şi personalul specializat pe activități educative. Mi-a fost facil accesul la această categorie deoarece cunosc marea majoritate a acestor cadre didactice. Tehnica eşantionării este eşantionarea aleatorie, iar tehnica utilizată este cea a bulgărelui de zăpadă.

Metoda folosită în acest studiu este interviul de tip semistructurat. Instrumentul de lucru este ghidul de interviu, ce are la bază un set de întrebări prestabilite, întrebări ce sunt detaliate şi completate de altele suplimentare, ulterior, pe teren în funcție de datele obținute până în acel moment.

Ghidul de interviu cuprinde teme legate de:

- experiența profesională a cadrelor didactice;

- activitățile desfăşurate în şcoală;

- relaționarea cadrelor didactice cu familiile copiilor;

- modul în care elevii participă la programul şcolar;

- atitudinea părinţilor faţă de instituția şcolară; 
- problemele care apar în relația părinte-elev-profesor din perspectiva specialiştilor;

- rezulatele şcolare înregistrate de elevi.

\section{Concluziile studiului}

Practicile parentale ce mențin un echilibru între sarcinile familiale şi profesionale, se referă la îndeplinirea obligațiilor cotidiene pe care părinții trebuie să le efectueze pentru copiii lor. Indeplinirea acestora realizează integrarea culturală în comunitatea umană, spirituală, de bază, iar familia dobândeşte identitatea sa culturală.

Menținerea condițiilor favorabile dezvoltării intelectuale şi personale a copilului este realizată de unele familii printr-un transfer al responsabilității educaționale către instituții de educație. Practic părinții îşi deleagă o parte din funcțiile educative pentru a-şi folosi timpul în scopul ascensiunii în ierarhia socială.

\section{Acknowledgment}

This paper is a result of a research made possible by the financial support of the Sectoral Operational Programme for Human Resources Development 2007-2013, co-financed by the European Social Fund, under the project POSDRU/159/1.5/S/132400 - "Young successful researchers - professional development in an international and interdisciplinary environment".

\section{References:}

Băran, Pescaru, Adina - Parteneriat în educație. Familie - școală - comunitate, Editura Aramis Print, Bucureşti, (2004);

Gheorghiu Mihai, Dinu, Analiză şi interventie in stiinţa socială, Editura Universitătiii“Alexandru Ioan Cuza”, Iaşi, (2005);

Ionescu, Ion, Sociologia şcolii, Editura Polirom, Iaşi, (1997)

Luckmann, Thomas; Berger, Peter, Construirea socială a realității, Editura ART, Bucureşti, (2004)

Strage, Amy A., Family context variables and the development of self-regulation in college students, in: Adolescence, Spring, (1998)

Stănciulescu, Elisabeta, Teorii sociologice ale educației, Editura Polirom, Iaşi, (1996) 


\section{Biodata}

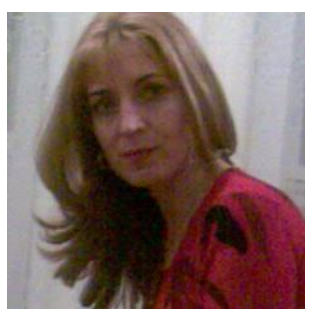

Teacher at "Vasile Alecsandri" Theoretical High School, Iasi, Costache Negri Str. No.50. web: www.lvais.ro. Main activity is teaching grades I-IV. Has studied at "Vasile Lupu" Pedagogical High School in Iasi and obtained a bachelor degree from "Al. I. Cuza" University in Iasi - Philosophy and Political Sciences Faculty. Presently, I'm managing an After School program through "Europrecepta" www.europrecepta.ro.

I have been working in the educational field for the last 27 years. I am interested in sociology and education.

Berea, G. (2015). Parental Work from a Sociological Perspective. Logos Universality Mentality Education Novelty, Section: Social Sciences, IV (1), 183-193. 